${ }^{16}$ Hekkens WTJM, Haex AF, Willighagen RGJ. Some aspects of gliadin fractionation and testing by a histochemical method. In: Booth CC, Dowling RH, eds. Coeliac disease. London: Churchill Livingstone, 1970:11.

17 Howdle PD, Ciclitira PJ, Simpson FG, Losowsky MS. Are all gliadins toxic in coeliac disease? Gut $1981 ; 22$ :A874.

${ }^{18}$ Kieffer M, Frazier PJ, Daniels NWR, Coombs RRA. Wheat gliadin fractions and other cereal antigens reactive with antibodies in the sera of coeliac patients. Clin Exp Immunol 1982;50:651-60.

${ }^{19}$ Savilahti E, Perkkio M, Kalimo K, Viander M, Vainio E, Reunala T. IgA anti-gliadin antibodies: a marker of mucosal damage in childhood coeliac disease. Lancet $1983 ; \mathrm{i}: 320-2$.

20 Unsworth DJ, Kieffer M, Holborrow EJ, Coombs RRA, Walker-Smith JA. IgA anti-gliadin antibodies in coeliac disease. Clin Exp Immunol $1981 ; 46: 286-93$.

${ }^{21}$ Kieffer M, Frazier PJ, Daniels WWR, Ciclitira P, Coombs RRA. Serum antibodies (measured by MrsPAH) to alcohol soluble gliadins in adult coeliac patients. F Immunol Methods $1981 ; 42: 129-36$.

${ }^{22}$ Logan RF, Tucker G, Rifkind EA, Heading RC, Ferguson A. Changes in clinical features of coeliac disease in adults in Edinburgh and the Lothians 1960-79. Br Med 7 1983;286:95-7.

${ }^{23}$ Stevens FM, Watt MD, Baker S, Egan-Mitchell B, McNicholl B, McCarthy CF. HLA antigens in coeliac patients and controls in the West of Ireland. In: McNicholl B, McCarthy CF, Fottrell PF, eds. Perspectives in coeliac disease. Lancaster: MTP Press, 1978:137.

24 O'Farrelly C, McKeever U, Weir DG, Feighery CF. Increased suppressor cell activity in coeliac disease. Irish $\mathcal{f} \mathrm{Med} S \mathrm{Si}$ (in press).

${ }^{25}$ O'Farrelly C, McKeever U, Feighery C, Whelan CA, Weir DG. Alpha gliadin sensitive suppression in coeliac disease. Gut 1982;23:A884.

(Accepted 12 April 1983)

\title{
Seminal fluid excretion of cytomegalovirus related to immunosuppression in homosexual men
}

\author{
ROBERT J BIGGAR, H KERZEL ANDERSEN, PETER EBBESEN, MADS MELBYE, \\ JAMES J GOEDERT, DEAN L MANN, DOUGLAS M STRONG
}

\begin{abstract}
Seminal fluid samples from 84 Danish homosexual men were successfully cultured to determine the prevalence of cytomegalovirus excretion. Ten (15\%) out of 66 men positive for the antibody were found to be excreting the virus. Although the proportion excreting was inversely related to age $(p<0.01)$, three men aged over 30 and with many years of homosexual experience excreted the virus. In addition, a 50 year old man with Kaposi's sarcoma excreted the virus. A further study of the ratio of $T$ cell helpers to suppressors in the men aged over 30 and a series of age matched non-excreting homosexual control or heterosexual men showed that those excreting cytomegalovirus in their seminal fluid had statistically lower ratios (all $<0.77$ ) than the controls $(\mathbf{p}<0.05)$.

Excretion of cytomegalovirus may be related to re-emergence of latent infection in immunosuppressed homosexual men.
\end{abstract}

Division of Cancer Cause and Prevention, National Institutes of Health, Bethesda, Maryland 20205, USA

ROBERT J BIGGAR, MD

JAMES J GOEDERT, MD

Institute of Medical Microbiology, University of Aarhus, Aarhus, Denmark

H KERZEL ANDERSEN, MD

Institute of Cancer Research, Aarhus, Denmark

PETER EBBESEN, MD

MADS MELBYE, medical student

Division of Cancer Biology and Diagnosis, National Institutes of Health

DEAN L MANN, MD

Department of Surgery, Uniformed Services University of Health Sciences, Bethesda, Maryland

DOUGLAS M STRONG, PHD

Correspondence and requests for reprints to: $\mathrm{Dr} R \mathrm{~J}$ Biggar, Landow Building 3CO8, Environmental Epidemiology Branch, Division of Cance Cause and Prevention, National Institutes of Health, Bethesda, Maryland 20205, USA.

\section{Introduction}

Homosexual men have a high prevalence of antibodies against cytomegalovirus. In a recent study in San Francisco $94 \%$ of 139 homosexual men had antibodies against cytomegalovirus compared with $54 \%$ of 70 heterosexual men. ${ }^{1}$ Data from Denmark show a similar difference in the prevalence of antibodies against cytomegalovirus between homosexual and heterosexual men. ${ }^{1 \mathrm{a}}$

Venereal transmission of cytomegalovirus may occur between heterosexuals ${ }^{2} 3$ and might explain the high prevalence of antibodies to cytomegalovirus in homosexual men. Cytomegalovirus is excreted in many body fluids, including seminal fluid. ${ }^{45}$ The frequency of isolation of the virus depends on the age and habits of the men under study. One per cent of men attending infertility clinics were found to be excreting cytomegalovirus in their seminal fluid, ${ }^{6} 7$ compared with four out of $64(6 \%)$ of sexually active male university students and men attending venereal disease clinics. ${ }^{6}$ Eight attempts to isolate cytomegalovirus from the urine and blood of three of these four men all yielded negative results. ${ }^{6}$ Thus seminal fluid may be the only body fluid in which excretion of cytomegalovirus can be shown.

No studies have focused on seminal fluid excretion of cytomegalovirus in homosexual men. Among 190 homosexual men in San Francisco, however, 7\% were excreting the virus in their urine compared with none of 101 similarly aged heterosexual men. ${ }^{1}$ Studies of cytomegalovirus in seminal fluid have included a few homosexual men-for example, two out of five seminal fluid samples positive for cytomegalovirus in one study were donated by homosexual men, but no information was given about how many homosexual men were studied. ${ }^{6}$ In another study of 389 Canadian men nine were known to be homosexual, and three of these were found to be excreting cytomegalovirus in the seminal fluid.?

We obtained seminal fluid samples from 101 homosexual Danish men in an effort to establish a more reliable estimate of the prevalence of excretion of cytomegalovirus in this fluid, as it is the most probable source of exposure in homosexual men. In addition, we determined the ratio of $T$ cell helpers to suppressors in selected men to examine the relation between viral excretion and immunosuppression. 


\section{Subjects and methods}

Seminal fluid samples were donated by members of two homosexual communities located in Copenhagen and Aarhus, Denmark. The study had been approved by the local ethics committees in both communities, and all men were volunteers. Within one hour of collection undiluted samples of seminal fluid $(0.2 \mathrm{ml})$ were placed into flasks containing monolayers of human lung fibroblasts with 1-2 $\mathrm{ml}$ of medium. After one hour at $37^{\circ} \mathrm{C}$ to allow for absorption the cells were washed to remove the seminal fluid, which is cytotoxic. ${ }^{5}$ Despite this, 17 cultures, including four from men lacking any antibody to cytomegalovirus, did not survive. Flasks were observed over six weeks for the characteristic cytopathic effect of cytomegalovirus, and isolates were confirmed by immune fluorescence methods. Sera from these men were also tested for complement fixing antibody against cytomegalovirus. The methods for culture of cytomegalovirus and antibody testing have been described previously. ${ }^{8}$

For immune studies peripheral blood mononuclear cells were separated and cryopreserved within two to three hours after being collected. Cryopreserved lymphocytes were sent to Bethesda, Maryland, for analysis of $\mathrm{T}$ cell subpopulations. Samples were sent in dry ice packing, care being taken to seal the samples away from the vaporising carbon dioxide. The ratios of $T$ cell helpers to suppressors were determined with a fluorescence activated cell sorter according to methods described previously. ${ }^{9}$ Monoclonal antibodies used as markers included the 3F10, OKT4, OKT8, and 9.6. These markers were used as indicators of antigens related to HLA, T cell helpers, $\mathrm{T}$ cell suppressors, and pan $\mathrm{T}$ cell antigens, respectively.

\section{Results}

Out of 84 successful cultures, 18 showed no antibody against cytomegalovirus. As expected, cytomegalovirus was not isolated from these $18 \mathrm{men}$. Cytomegalovirus was isolated from the seminal fluid of $10(15 \%)$ of the remaining 66 men. Younger men were more likely to be excreting cytomegalovirus than older men $(p<0.01$, Spearman's rank order correlation; table).

The men from Aarhus who were excreting cytomegalovirus in their seminal fluid ranged from 18 to 27 years old and, with one exception, had had relatively little homosexual experience (one, two, two, two, four, and 13 years). By contrast, the men from Copenhagen who were excreting cytomegalovirus were considerably older $(26,32$, 36 , and 39 years). They reported many years of homosexual activity (seven, 18,21, and 10, respectively) and many different sexual partners a year $(40,15,10$, and 50 respectively), and had probably sustained the primary infection long ago. Excretion of cytomegalovirus correlated inversely with years of homosexual experience $(p<0.07$, Spearman rank order correlation). Only two men, one in Aarhus and one in Copenhagen, admitted having used nitrite inhalants in the past 12 months.

Excretion of cytomegalovirus in seminal fluid of Danish homosexual men

\begin{tabular}{|c|c|c|c|c|c|}
\hline $\begin{array}{c}\text { Age } \\
\text { (years) }\end{array}$ & $\begin{array}{c}\text { No of } \\
\text { samples } \\
\text { obtained }\end{array}$ & $\begin{array}{l}\text { No of } \\
\text { cultures } \\
\text { that died }\end{array}$ & $\begin{array}{c}\text { No of } \\
\text { cultures } \\
\text { that } \\
\text { survived }\end{array}$ & $\begin{array}{c}\text { No of } \\
\text { patients } \\
\text { with } \\
\text { antibodies to } \\
\text { cytomegalovirus }\end{array}$ & $\begin{array}{c}\text { No (\%) } \\
\text { excreting } \\
\text { cytomegalovirus }\end{array}$ \\
\hline \multicolumn{6}{|c|}{ Copenhagen } \\
\hline $\begin{array}{r}<20 \\
20-29 \\
30-39 \\
>40 \\
?\end{array}$ & $\begin{array}{r}0 \\
12 \\
22 \\
11 \\
3\end{array}$ & $\begin{array}{l}2 \\
1 \\
1\end{array}$ & $\begin{array}{r}10 \\
21 \\
10 \\
3\end{array}$ & $\begin{array}{r}8 \\
17 \\
9 \\
3\end{array}$ & $\begin{array}{l}1(13) \\
3(18)\end{array}$ \\
\hline All ages & 48 & 4 & 44 & 37 & $4(11)$ \\
\hline $\begin{array}{c}<20 \\
20-29 \\
30-39 \\
>40 \\
?\end{array}$ & $\begin{array}{r}3 \\
30 \\
12 \\
4 \\
4\end{array}$ & $\begin{array}{l}8 \\
2 \\
1 \\
2\end{array}$ & $\begin{array}{r}\text { Aarhus } \\
3 \\
22 \\
10 \\
3 \\
2\end{array}$ & $\begin{array}{r}3 \\
15 \\
7 \\
3 \\
1\end{array}$ & $\begin{array}{l}2(67) \\
4(27)\end{array}$ \\
\hline All ages & 53 & 13 & 40 & 29 & $6(21)$ \\
\hline $\begin{array}{r}<20 \\
20-29 \\
30-39 \\
>40 \\
?\end{array}$ & $\begin{array}{r}3 \\
42 \\
34 \\
15 \\
7\end{array}$ & $\begin{array}{r}10 \\
3 \\
2 \\
2\end{array}$ & $\begin{array}{r}\text { Total } \\
3 \\
32 \\
31 \\
13 \\
5\end{array}$ & $\begin{array}{r}3 \\
23 \\
24 \\
12 \\
4\end{array}$ & $\begin{array}{l}2(67) \\
5(22) \\
3(13)\end{array}$ \\
\hline All ages & 101 & 17 & 84 & 66 & $10(15)$ \\
\hline
\end{tabular}

In the 10 samples positive for cytomegalovirus excretion ranged from one to 50000 plaque forming units per $0.2 \mathrm{ml}$ aliquot and did not correlate with age. In the three men aged over 30 , titres were 1000 , one, and 50 plaque forming units per $0.2 \mathrm{ml}$ aliquot.

In addition we cultured a sample of seminal fluid from a 50 year old homosexual with Kaposi's sarcoma and persistent immunosuppression, although he had never been treated with immunosuppressive drugs or radiation. Details of his condition have been reported previously. ${ }^{10} \mathrm{He}$ was also found to be excreting cytomegalovirus (10 plaque forming units per $0.2 \mathrm{ml}$ aliquot).

To determine whether more experienced homosexual men who were excreting cytomegalovirus in their seminal fluid samples were immunocompromised we evaluated the ratio of $T$ cell helpers to suppressors in the following subjects: the three men aged over 30 who were excreting the virus; the 50 year old patient with Kaposi's sarcoma (also excreting); four homosexual men from the same community and four homosexuals from a different community matched for age who were not excreting the virus; and four heterosexual male controls in the same age range. The figure shows the results. The difference in the ratio between the homosexual men aged over 30 who did and did not excrete the virus was significant $(p<0.05$, Student's $t$ test, two-tailed). Although it would have been of additional interest to examine the ratio of $T$ cell helpers to suppressors in the 27 year old man from Aarhus who was excreting cytomegalovirus despite 13 years of homosexual experience, he was not available for sampling.

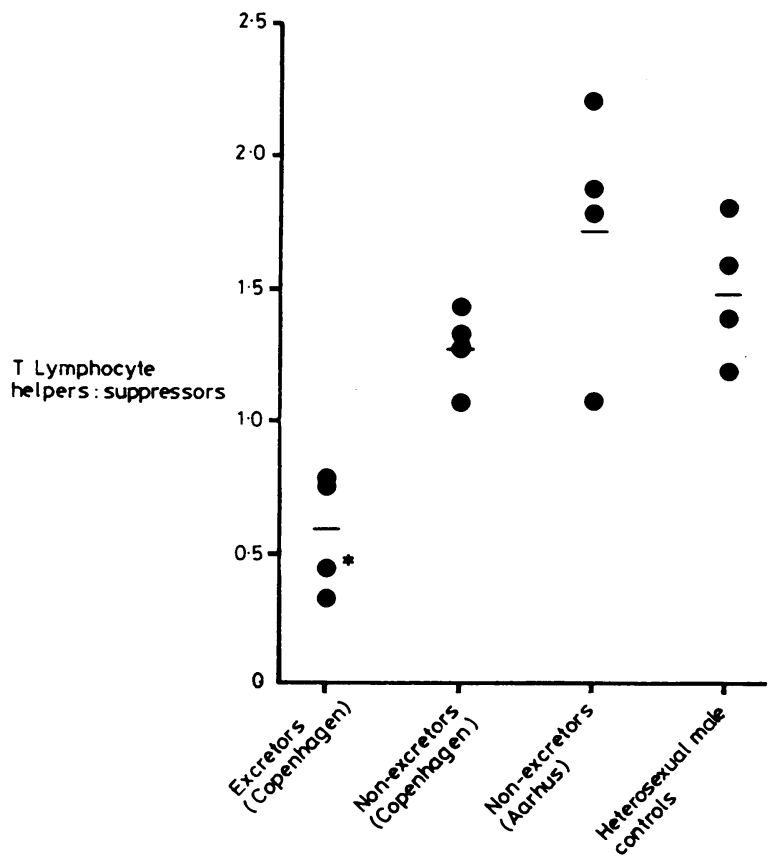

Ratios of $\mathrm{T}$ lymphocyte helpers to suppressors in healthy Danish homosexual men who either were or were not excreting cytomegalovirus in their seminal fluid, and in heterosexual male controls. (Bars indicate mean values.)

*Patient with Kaposi's sarcoma.

\section{Discussion}

These results indicate that excretion of cytomegalovirus in the seminal fluid of homosexual men is common and related to age. This relation with age has been observed in studies of excretion of cytomegalovirus in the urine of women ${ }^{11}$ and men ${ }^{1}$ and has been attributed to recent primary infection in those donating samples. Excretion of cytomegalovirus in younger homosexual men, particularly those who have recently initiated a homosexual lifestyle, might be expected if they are examined soon after contracting a primary infection. In contrast to other studies, however, in which all people excreting the virus were aged under 30, we found that three of the four homosexual men from Copenhagen who were excreting the virus were over 30 . 
All three had had many years of homosexual activity and many different sexual partners a year, and therefore their primary infections had probably occurred many years earlier. Our finding of excretion of the virus in these men might indicate that some homosexual men continue to excrete cytomegalovirus in seminal fluid over many years or, alternatively, that there had been recent reinfection, perhaps with a different strain of cytomegalovirus. More probably, however, latent cytomegalovirus re-emerges in men with immunosuppression.

Recently there have been many reports of homosexual men developing illnesses, including Kaposi's sarcoma, that are related to immune suppression. Clinical and epidemiological aspects of these illnesses were recently summarised..$^{12}$ Evidence of abnormal ratios of $\mathrm{T}$ cell helpers to suppressors in apparently healthy homosexual men has also been documented, ${ }^{13}$ and the low ratios reported are similar to those that we found in the older homosexual men who were excreting cytomegalovirus in their seminal fluid. Excretion of cytomegalovirus in the seminal fluid of these more experienced homosexual men and of a homosexual patient with Kaposi's sarcoma is therefore probably the result of immune dysfunction.

This study was supported in part by National Cancer Institute contract Y01CP00502.

\section{References}

${ }^{1}$ Drew WL, Mintz L, Miner RC, Sands M, Ketterer B. Prevalence of cytomegalovirus infection in homosexual men. $\mathcal{f}$ Infect Dis $1981 ; 143$ : 188-92. 1a Melbye M, Biggar RJ, Ebbesen P, Andersen HK, Vestergaard BF. Lifestyle and anti-viral antibody studies among homosexual men in Denmark. Acta Pathol Microbiol Scand (in press).

${ }^{2}$ Jordan MC, Rousseau WE, Noble GR, Stewart JA, Chin TDY. Association of cervical cytomegalovirus with venereal disease. $N$ Engl f Med 1973;288:932-4.

${ }^{3}$ Chretien JH, McGinniss CG, Muller A. Venereal causes of cytomegalovirus mononucleosis. $\mathcal{F} A M A$ 1977;238:1644-5.

4 Lang DJ, Kummer DF. Demonstration of cytomegalovirus in semen. N Engl f Med 1972;287:756-8.

5 Lang DJ, Kummer JF, Hartley DP. Cytomegalovirus in semen: persistence and demonstration in extracellular fluids. $N \mathrm{Engl} \mathrm{f} \mathrm{Med}$ $1974 ; 291: 121-3$.

${ }^{6}$ Lang DJ, Kummer JF. Cytomegalovirus in semen: observations in selected populations. F Infect Dis 1975;132:472-3.

7 Embil JA, Manuel FR, Gainer JB, Coveney L. Cytomegalovirus in the seminal fluid. Can Med Assoc $\mathcal{F} 1982 ; 126: 391-2$.

${ }^{8}$ Andersen $\mathrm{HK}$, Brostrom $\mathrm{K}$, Hansen B, et al. A prospective study of the incidence and significance of congenital cytomegalovirus infection. Acta Paediatr Scand 1979;68:328-36.

${ }^{9}$ Goedert JJ, Neuland CY, Wallen WC, et al. Amyl nitrite may alter $T$ lymphocytes in homosexual men. Lancet $1982 ; \mathrm{i}: 412-5$.

10 Gerstoft J, Malchow-Moller A, Bygbjerg IC, et al. Erhvervet immundefekt hos homosexuelle maend: en nyt sygdomsbillede. (Acquired immunological defect in homosexual men : a new clinical picture.) Ugeskr Laeger $1982 ; 144: 771-6$.

11 Knox GE, Pass RF, Reynolds DW, Stagno S, Alford CA. Comparative prevalence of subclinical cytomegalovirus and herpes simplex infections in the genital and urinary tracts of low-income, urban women. f Infect Dis 1979;140:419-22.

12 CDC Task Force on Kaposi's sarcoma and Opportunistic Infections Epidemiologic aspects of the current outbreak of Kaposi's sarcoma and opportunistic infections. N Engl f Med $1982 ; 306: 248-52$.

${ }^{13}$ Wallace JI, Coral FS, Rimm IJ, et al. T-cell ratios in homosexuals. Lancet $1982 ; \mathrm{i}: 908$.

(Accepted 7 April 1983)

\title{
Schistosomiasis mekongi diagnosed by rectal biopsy
}

\author{
G LORETTE，M R JAAFAR， M F GROJEAN， Th DUONG
}

\begin{abstract}
Schistosoma mekongi, a parasite of the dog which is endemic in small foci along the Mekong river, is rarely seen in Europe. A case of schistosomiasis caused by $\mathbf{S}$ mekongi was recently seen in France, in a native of Laos who had been living in Thailand. He was admitted for treatment of previous diagnosed tuberculoid leprosy but was found to have hepatosplenomegaly, with a high eosinophil count and high bilirubin concentrations. Serological examination suggested schistosomiasis, but there were no parasites in the urine and the rectal mucosa looked normal on endoscopy. Nevertheless, rectal biopsy showed schistosomal proctitis and many ova of $S$ mekongi. Two courses of praziquantel cleared the ova from his rectal mucosa.
\end{abstract}

Although serological examination using $\mathbf{S}$ mansoni

Service de Dermatologie, Centre Hospitalier Universitaire

Trousseau, 37044 Tours, France

G LORETTE, MD, médecin adjoint

$M$ R JAAFAR, $M D$, attaché

M F GROJEAN, MD, chef de clinique-assistant

Laboratoire de Parasitologie, Centre Hospitalier Universitaire

Trousseau, 37044 Tours, France

TH DUONG, MD, médecin assistant antigen suggested schistosomiasis, only biopsy of normal looking rectal mucosa allowed the diagnosis to be established.

\section{Introduction}

Schistosoma mekongi is a parasite of the dog. It is endemic in small foci along the Mekong river in Laos and Thailand.'

\section{Case report}

A 21 year old man was admitted for the supervision of his tuberculoid leprosy, diagnosed two years before, and treated with sulphones (dapsone). He was a native of Vientiane (Laos), but had lived in Thailand for two and a half years before his arrival in France. He complained of right hypochondrial pain and had slight conjunctival jaundice. Clinical examination showed hepatosplenomegaly, the spleen extended beyond the costal rim by $3 \mathrm{~cm}$. Blood examination showed hypereosinophilia $\left(8.96 \times 10^{8} / 1\right)$. The total bilirubin concentration was high at $26 \mu \mathrm{mol} / \mathrm{l}(1.5 \mathrm{mg} / 100 \mathrm{ml})$ with a ratio of total to conjugated bilirubin of $7: 1$. Examination of the faeces showed some eggs of Opisthorchis viverrini and some larvae of Anguillula. A serodiagnosis of schistosomiasis was made after an indirect immunofluorescence technique showed a positive response to the antigen $S$ mansoni at a titre of $1 / 40$. There were no parasites in the urine. Rectal endoscopy showed no abnormal changes, but histological examination of two rectal biopsy specimens taken from normal looking rectal mucosa showed lesions of schistosomal proctitis and the presence of 